\title{
ZAKAH FOR ASNAF AL-GHARIMUN IN BRUNEI DARUSSALAM: CONCEPTS AND PRACTICES
}

\author{
Rose Abdullah ${ }^{1}$, Abdurrahman Raden Aji Haqqi ${ }^{2}$
}

\begin{abstract}
Zakah for Asnaf Al-Gharimun in Brunei Darussalam: Concepts and Practices. This research paper discusses the concepts of debt in Islam in relation to the category of al-gharimun that entitle for receive zakah. The data from the authority department has shown an alarming increase in number of applicant for zakah under the category of asnaf Al-Gharimun. Why was the number increased and who are actually eligible to receive zakah under the category of Al-Gharimun? This paper tries to answer these questions. The concept of debt in al-Qur'an will be discussed and various discussions by Islamic scholars and researchers will be analysed. Data gathered from several officers of Islamic Religious Council of Brunei Darussalam through personal interviews. The phenomenon was due to misunderstanding and ignorant among the public with regards to what kind of debts that are eligible under the category of Al-Gharimun to receive zakah.
\end{abstract}

Keywords: zakah management, al-gharimun, qualitative

\begin{abstract}
Abstrak. Zakat Untuk Asnaf Orang yang Berhutang di Brunei Darussalam: Konsep dan Penerapan. Artikel ini membahas konsep hutang dalam Islam terkait hubungannya dengan kategori orang yang berhutang (algharimun) yang layak menerima zakat. Data pada otoritas terkait menunjukkan bahwa terjadi peningkatan jumlah pendaftar penerima zakat pada kategori ini. Mengapa jumlah ini meningkat dan siapakah yang sebenarnya layak untuk menerima zakat pada kategori al-gharimun ini? Artikel ini berupaya menjawab hal tersebut. Konsep tentang hutang dalam Al-Qur'an akan didiskusikan, selain itu akan mengkaji pula berbagai temuan yang telah dibahas oleh para peneliti dan sarjana muslim. Data yang dipergunakan berasal dari kantor urusan agama Islam di Brunei Darussalam dengan mekanisme wawancara. Hasil penelitian menunjukkan bahwa fenomena meningkatkan jumlah pendaftar ini terkait kesalahanpahaman dan ketidakpedulian public terkait siapa yang sebenarnya layak untuk menerima zakat dalam kategori orang yang berhutang ini (algharimun).
\end{abstract}

Kata kunci: pengelolaan zakat, orang yang berhutang, kualitatif 


\section{Introduction}

The obligatory nature of zakah is firmly established in the Al-Qur'an and the ahadith. The Al Qur'an clearly mentioned, in many verses, the responsibility of the rich to pay zakah and in fact, this is always mentioned after the injunction of solat/prayer (Al-Qardawi translated by Kahf, 2005). In the Qur'an, Surah AlTaubah 9:103, Allah ordered the Prophet to collect zakah. To those who refuse to pay zakah, Allah states the penalty in Surah Al-Taubah 9:34-35. For those who do not pay zakah, the Prophet Muhammad (PBUH) mentioned the penalty as reported in Sahih Bukhari, volume 2, Book 24, Number 486, as narrated by Abu Huraira:

Allah's Apostle said, 'Whoever is made wealthy by Allah and does not pay the zakah of his wealth, then on the Day of Resurrection his wealth will be made like a bald-headed poisonous male snake with two black spots over the eyes. The snake will encircle his neck and bite his cheeks and say, "I am your wealth, I am your treasure."'

According to Yusuf Ali's translation of Surah Al-Dhariyat 51:19, the following is mentioned: 'And in their wealth and possessions (was remembered) the right of the (needy,) him who asked, and him who (for some reason) was prevented (from asking).' This indicates that zakah is not charity which is voluntarily given by wealthy people but rather the right of the poor on the wealth of the rich. It is a responsibility and a must for the rich to give zakah to the poor and destitute as well as other qualified recipients.

Therefore, an efficient management of zakah is crucial in the Islamic economic development. In Brunei Darussalam, the issue of accumulated zakah fund since 1960s amounted to more than BND $\$ 230$ million had raised the attention of the His Majesty in 2009. His Majesty's speech (titah) during the Brunei Islamic Religious Council (MUIB) Meeting in 2009 highlighted that the zakah distribution might also consider to help those indebted for an acceptable reasons particularly those who were destitute and could not afford to pay their government housing debts and other basic necessities. Since then, it was reported that MUIB received more than $50 \%$ of the 5,000 applications for zakah assistance was under the alGharimun category (MUIB, 2014).

However, the number of recipients under the category of al-gharimun since 2009 were only 69 persons (2.3\%) of the total applicant (MUIB, 2014). Does it mean that the applicants were not the right people? Who are the applicants? Are they really entitled to receive zakah as al-gharimun? What kind of debt that can be considered as al-gharimun to receive zakah? This paper tries to answer these questions. 
Therefore, the discussion will be continued with exploration on the concepts of debt in Islam in section 2. Then it will be followed by Section 3, brings the detail discussion on zakah disbursement to the group of al-gharimun in Brunei Darussalam, before conclusion in the last section.

\section{Literature Review}

Debt is an issue that afflicts many Muslims, including the seemingly wealthy, and is something that is not adequately addressed. This is due most likely, to a lack of knowledge on the issue, as well as a lack of awareness of the problem itself. There are several Arabic words that imply indebtedness such as Qard, Dayn, Salaf, and 'Ariyyah. All these words are familiar in the discourses of Islamic jurisprudence. They are like loan, borrow and debt in English.

Debt in Arabic term known as Dayn which is rooted in the same root with Din i.e da ya na, which implies any right or property that is payable upon a person either to another person or his Lord based on commitment towards that person or his Lord (Ministry of Awqaf and Islamic Affairs, Kuwait, nd). This covers two dimensions namely the right of one's fellow human beings and the right of Allah. The first dimensions will be all rights arising from financial transactions such as sale contract, lease, credit and rental, or from non-financial transactions such as the dowry of a woman, the cost of damage and the cost of crimes. It also covers the rights, which arise from services.

The latter dimension is more comprehensive in sense that all mankind in this world are being indebted to Allah, the Creator. It includes all religious matters especially that involve the relationship between a man and his Lord such as missing prayers, missing zakah, or sawm. Besides, the debt may be a right or a wealth; it may also in kind as well as in cash. Debt is inevitable element of one's life. Thus Islam commands its adherents to fulfill their obligation either towards (debt to) mankind or Allah (Mahboob, 2010).

In the terminology of Islamic framework, Qard and Dayn relate to the giving or taking of loans. However, the word Dayn has a broader connotation then the word Qard. Dayn incurs in any way which leaves a debt as a liability to another party to be paid later without any profit over the principal amounts (Ministry of Awqaf and Islamic Affairs, Kuwait, nd). Whereas, Qard, from root qa ra da could be defined as an interest-free loan for needy borrowers extended on a goodwill basis; in particular al-Qard al-Hasan provides funds for humanitarian and welfare purposes without any profit accruing to the lender (al-Zuhaili, 1989).

In fact, Qard consists on giving ownership of anything having value for the 
benefit of another by way of virtue (The Mejelle, nd). The ownership of the loaned objects is transferred to the borrower who can use, buy, sell, or donate them as the borrower wishes. Qard is only applied when one gets obliged to return the equivalent of the thing taken and repayment is for the same amount as the amount lent. Goods of the same kind will be paid back on demand or at the settled time. Qard should not bring any return or addition to the lender because that would be equivalent to taking Riba. However, a borrower can pay more than the amount borrowed, but it must not be stipulated in the contract. Further, the date of payment of the loan may or may not be included in the Qard contract as the lender can demand repayment at any time. And the loan should not be conditional upon any other contract, such as Bay' and vice-versa.

Ariyya is another structure of borrowing goods in a virtuous act (alShirbini, nd). However, in the case of 'Ariyya, the exact borrowed commodity has to be returned to its owner, not any replacement. While in Qard, the same kind of the loaned commodity with essentially the same nature or character could be paid back.

On the other hand, a Dayn is the result of any contract or credit transaction. The created debts ought to be returned without any profit over their principal amounts. Salaf is a form of Dayn that is similar to Salam (al-Shirbini, nd). It is used for a loan of fixed tenure and in that sense it is closer to Dayn; Salaf includes loans for short, intermediate and long term loans and the price of the commodity is paid in advance, while it is delivered at a future date. The amount given as Salaf cannot be called back before its due date. Therefore, this creates a liability for the seller to supply the commodity in the future.

Allah said in the Holy Quran Surah al-Baqarah 2:282, to the effect: "O ye who believe! When ye deal with each other, in transactions involving future obligations in a fixed period of time, reduce them to writing Let a scribe write down faithfully as between the parties: let not the scribe refuse to write: as Allah Has taught him, so let him write. Let him who incurs the liability dictate, but let him fear His Lord Allah, and not diminish aught of what he owes. If the party liable is mentally deficient, or weak, or unable Himself to dictate, Let his guardian dictate faithfully, and get two witnesses, out of your own men, and if there are not two men, then a man and two women, such as ye choose, for witnesses, so that if one of them errs, the other can remind her. The witnesses should not refuse when they are called on (For evidence). Disdain not to reduce to writing (your contract) for a future period, whether it be small or big: it is just in the sight of Allah, More suitable as evidence, and more convenient to prevent doubts among yourselves but if it be a transaction which ye carry out on the spot among yourselves, there is no blame on you if ye reduce it not to writing. But take witness whenever ye make a commercial contract; and let neither scribe 
nor witness suffer harm. If ye do (such harm), it would be wickedness in you. So fear Allah. For it is God that teaches you. And Allah is well acquainted with all things.

It is the order of the Holy Qur'an, when the matters of borrowing money arise, whether it be for small or large amounts, it should be written down in a contract. Also, if possible this transaction should take place in front of two witnesses, so that there is no dispute at a later stage. Some scholars state it is preferable and some state it compulsory to write down a loan transaction. If for any reason, in the future there is a dispute, this written document can be produced as proof. In the Shari'ah, it is not a sin to take a loan (non-interest) in the state of necessity. However, to not return or repay the borrowed money is oppression and a sin.

In line with the debt toward mankind, it has been restricted in Islam, in the sense that it should be paid back without involving injustice between the debtor and creditor. Islam encourages Muslims to help each other. In Islam to give loan is better than to give charity. In fact Islam prohibits any acts of begging. For it may humiliate the doers. As Prophet Muhammad (peace be upon him) once was asked by the companion by the name Qubaisah to help him to repay the debt. The Prophet (PBUH) then said, "Wait until one gives a charity than we will give it to you" then the Prophet (PBUH) said, "Begging is prohibited except in three conditions; one is being indebted and fails to pay it back, the begging is permissible until he fully paid back then he stops begging, one whose property was damaged by the natural disasters so that the begging is permissible until he received a sufficient assistance to survive, and finally the poor and needy one whom has been witnessed by three trustworthy people in his community, the begging is permissible to fulfil his needs. Qubaisah, other than three above mentioned, begging is prohibited and those who do it, they eat unlawful things".

Thus one who takes credit or loan and repays it back is better and respected than those who receive charity. However, Islam has commanded Muslims to give and take debt that is free interest based or Qard Hasan. As Allah says in Surah alBaqarah 2:245, to the effect:

"Who is he that will loan to Allah a beautiful loan, which Allah will double unto his credit and multiply many time? It is Allah that giveth (you) want or plenty, and to Him shall be your return".

Al-Qard al-Hassan means a beautiful loan that does not carry any value added to the principle that is borrowed. In Islamic bank practices, it refers to a credit or loan in which the debtor uses it for the good purposes and later on he has to pay only the same amount with that he took from the bank.

The word dayn (debt) in the Arabic language implies submission and humiliation. The relationship between the linguistic and legal definitions is thus, 
obvious. The debtor who is known as madin is akin to being a detained person or a prisoner, as described in the following Prophetic tradition: "Your companion is being detained by his debt” (Abu Daud, Sulaiman, 1952). Moreover, Muslim jurists agree that debt (dayn) is a financial obligation that must be discharged as mentioned above. The Holy Quran uses the term gharim (debtor) to describe any indebted person failing to repay his debt as it is clearly stated in ayah 60 Surah al-Taubah. According to Abu Hanifah (d. 765AD) however, a debtor is one who carries a debt and is unable to accumulate the nisab over his debt (Ibn Nujaim, Zainuddin, 1997). Such an indebted is considered to be poor and hence entitled to zakah (Al-Mawardi, 1386/1966).

Muslim jurists such as Malik (d.795), Shafíi (d.820) and Ahmad (d.855) argue that debt, whether personal or public, may be held on behalf of the individual or group (Al-Zuhaili, 1989). Personal debt may be utilized in the purchase of a shelter, furniture, medicine; or in building a home, being used in marriage as well as in other non-extravagant expenses. Debts incurred on behalf of the public however, entitle debtors to repayment from the Muslim public treasury. Similarly, personal debts that exhaust one's wealth are either used in dealing with circumstances of exigency such as natural disasters or in acquiring bare necessities; all of which would also be paid from zakah or endowment funds. It should be noted however, that according to Islamic law, the clearance of debts from zakah funds requires a verification of the legitimate needs of the debtors; this should not necessarily represent a case of financial destitution. Debtors' assets include homes, clothing, beds, utensils, servants and transport, but should however, -when necessary- stay out of the creditors' grasp (al-Qardawi, 2005).

Debts incurred on behalf of the public in the good interest and benefit of other individuals or the community; as in cases of reconciliation are considered to be a rewarding charity. The noble acts of such individuals extinguish enmity, hatred and disunity, while effectively building peace and harmony. Islam accords said individuals an honourable status and grants them the legal right of payment of their incurred debts from zakah even when reconciliation is made among non-Muslim groups. According to the Shafi'i School of Law, debts incurred for beneficial public services qualify for zakah coverage even when the debtors themselves are wealthy. This is logically understandable in light of Islam's decided interest in the building of community understanding, reconciliation and cohesion.

Indebtedness incurred for the good of the community and causes related to it further demonstrate that debt is capable of acquiring an inherently positive social value and may turn into a highly recommended act of piety and nobility. It further follows that philanthropic/charitable contributions made specifically for the community's public interest including the establishment of learning institutions, 
places of worship, hospitals and orphanages are deserving of financial attention from the state treasury (Benaouda Bensaid, 2013).

Debt in Islam is long last liability that does not limit in this world but it is also liability in the hereafter as well. As a result, whatever debt the deceased had, in estate distribution for example, the heirs should settle it first, before the estate is distributed to eligible heirs.

Indebtedness however, does not remove from religious piety and morality. The Prophet Muhammad himself at one point was indebted and faced difficulties in paying it off. His example on indebtedness reveals legitimacy in the life of the Muslim individual and the community. As such, the crucial point is repaying debt back while maintaining the community and state of religious and moral responsibility. 'Aisha the wife of the Prophet reported that he bought foodstuffs on credit for a limited period of time and mortgaged his armour for it (Al-Bukhari, Muhammad ibn Ismail. (1407/1987). He is also reported to have borrowed a camel from a Bedouin at a time of scarcity for the poor who were deserving beneficiaries of zakah. He wanted to slaughter the camel to feed them or to sell it and buy provisions for them. One also comes across Ibn 'Umar's advice to Humran in which he said: "Oh Humran, fear God and do not die in debt, lest it be taken from your good deeds when there will be no dinars and no dirhams". The religious texts cited above provide legitimate allowances for debts regarding which Muslim scholars have stipulated three conditions; namely that the borrower should be determined for repayment; in essence that it should be known or most likely expected that the debtor is able to repay it; and that the loan should be made for items of religious permissibility (Benaouda Bensaid, 2013).

Debt has its strict rules and regulations in Islam. For one, interest is completely forbidden. Additionally, while debt is discouraged, for cases where a person must borrow money, the debtor and lender must enter into a contract, the rules of which are clearly stipulated in the Quran. In cases where a debtor has made the mistake of taking debt on interest, all efforts should be sought to get rid of the interest. When not possible immediately, the debtor should seek all means to reduce payment of interest rates on repayment of debt, whether through debt consolidation or other means - until the debt is paid off completely. Hence it is recommended when debt is done the following steps should be done: First, to specify the period of the loan, i.e., the length of time after which the loan must be repaid. Second, writing down the loan and the time when it is to be repaid. Third, if the one who writes down the loan is a person other than the debtor, then the debtor is the one who should dictate to him the details of the loan. Fourth, if the debtor is unable to dictate because of sickness or some other reason, then the one who should dictate on his behalf is his guardian. Fifth, the loan should be witnessed, and the witnesses should be two men, 
or one man and two women. Sixth, the lender has the right to ask the borrower to guarantee the loan with a pledge which the lender will keep. The benefit of the pledge is that if the time comes for the debt to be repaid and the borrower refuses to pay, the item in pledge may be sold and the debt paid with that money; anything left over is to be given to the owner of the pledge, namely the debtor.

Guaranteeing a debt in one of these three ways (writing, witnesses or pledge) is mustahabb and is preferable, but it is not obligatory. Some of the scholars are of the view that it is obligatory to write down a loan, but most of the scholars say that it is mustahabb, and this is the more correct view. The reason for that is to protect people's rights so that they will not be exposed to loss because of forgetfulness or confusion, and as a precaution against those who do not fear Allah.

\section{Method}

This exploratory study uses mixed methodologies that are descriptive and content analysis on the literatures review related to distribution of zakah to the algharimun category. This paper uses critical analysis to examine various literatures that discuss the concept of debt in Islam, legitimacy of debt in Islam, the condition of eligibility for zakah and other related literatures with regards to the indebtedness category of zakah recipients from different views of Islamic scholars.

Content analysis is a suitable research method for rigorous exploration of many important but difficult-to-study issues of interest to organizational researchers in areas as diverse as business policy and strategy, managerial and organizational cognition, organizational behavior and theory, and management (Duriau, et.al. 2007). Content analysis is an important bridge between purely quantitative and purely qualitative research methods. Content analysis allows the researchers to analyse socio-cognitive and conceptual constructs from the data (Pfarrer, et.al, 2010). The data and information on the zakah for al-gharimun in Brunei Darussalam were collected by conducting interview with two officers in-charge from Brunei Islamic Religious Council (MUIB) on 2 June 2015.

\section{Result and Discussion}

\section{Situation of al-Gharimun in Which He Deserved Zakah}

As mentioned earlier, the Holy Qur'an stated al-Gharimun in ayat 60 Surah al-Taubah which says to the effect: "The alms are only for the poor and the needy, and for those employed in connections therewith, and for those whose hearts are to be reconciled, and for the freeing of slaves, and for those in debt, and for the cause of Allah, and for the wayfarer - an ordinance from Allah. And Allah is All-Knowing, Wise." 
"People under debt", as explained by al-Qardawi, include those hit by disasters Individuals struck by natural disasters or accidents are not left to voluntary charity alone. They are given a share in the proceeds of zakah. The Prophet told Qubaisah, "Asking is not permissible, except in three cases." The Prophet mentioned among them a man struck by a disaster that wipes out his wealth. Early commentators on the Qur'an include in the category of persons under debt [al gharimin] "He whose house caught fire or whose wealth was wiped out by flood or who has debts that burden his family." How much are such persons given? In the saying mentioned above, the Prophet (p) says such a person may ask "until he secures sufficiency of sustenance". This undoubtedly differs from one person to another, depending on factors such as the general standards of living, size of family, and social status. For a merchant whose inventory is burned, for example, securing sustenance of living may require purchasing a minimum amount of inventory sufficient for his type of business. Some jurists even argue that such people must be given amounts sufficient to put them back on their feet at the level they had before the accident took place. Al-Qardawi (2005) mentioned "I believe what determines how much persons struck by disasters should be given depends on the availability of funds in the zakah agency and on several other factors, namely other needs that draw on these funds. Lastly, it must be emphasized that the rural areas of today's Muslim countries desperately need such Islamic insurance against the financial aftermath of natural disasters and drought, because of predominant poverty and insufficiency of voluntary charity to take total responsibility for such insurance."

Al-Gharimun's Religious and Moral Responsibility: The negative influences of financial responsibilities that have yet to be discharged, is that it can spoil the purity of worship. It potentially religiously affects the acceptance of piety and religious deeds even for those who sacrifice their own lives for God. Islam gives due attention to the al-Gharimun's intention, thought and moral commitment to debt payment. In fact, Islam grants positive commitment as shown in divine assistance to debt payment and decries any negative thoughts towards loans and debts. This extends beyond the superficial face of contracts and agreements to deeply touch on the spiritual, moral and emotional state of Muslim religious life while constantly reinforcing financial trust and security. It is in this context that we grasp the implications of the tradition of the Prophet in which he is reported to have said: "Whoever takes people's money (by debt) with the intention of paying it back, God will pay it back on his behalf and whoever takes it with the intention of usurping it, God will destroy him". ${ }^{1}$

\footnotetext{
${ }^{1}$ Narrated by al-Bukhari.
} 
God's paying the debtor's loan speaks not only of a sort of divine interference, but also characterizes a strong religious presence in Muslim financial management. It merges the sacred with the profane. Hence, it is understood why thoughts and decisions of financial unaccountability cause a life of difficulty and hardship, a lack of blessings, in addition to the incurring of severe consequences in the Hereafter. Muslims are thus instructed to clear their outstanding debts first, as reported in the following tradition; "Deferring of paying outstanding debts on the part of rich people is injustice" (Muslim, 1956). Other similar traditions invoke not only torment and punishment in the eschatological world, but raise the equally important issue of credibility and honour. This is understood in accordance with the saying of the Prophet in which he is reported to have said; "The delay of a capable man in paying his debts desecrates his honour and makes him liable to punishment". This meaning is significant for it effectively links the individual's self-worth to morality while sustaining the societal fabric through individual financial prudence first followed by the application of law.

Indebtedness and Muslim Integrity: In this section we shall examine the religious and moral implications of debt for Muslims and more specifically; understand how debt affects the integrity of Muslims. In a commonly used religious invocation, Muslims seek refuge in God from excessive debt (ghalabat al-dayn) and the abuse of people; the prime contention being that indebtedness results in inevitable stressful and abusive conditions.

The recitation of such an invocation connects Muslims to their real world while maintaining a religious awareness of financial planning, responsibility and accountability.

Muslims' over-indebtedness affects their religious integrity in varying degrees. In the spiritual world, Muslims strive to liberate their minds and souls from all sorts of pressures that might affect their religious and physical health. Pilgrimage for instance explains the need of Muslims to discharge their financial duties so that their religious integrity become at stake. Prior to Hajj, Muslim are religiously recommended as well as culturally accustomed to clearing their personal debts and fixing issues pertaining to public rights. In fact, according to a number of Muslims jurists, Muslims are not permitted to perform the obligation of pilgrimage with debts and loans. Other legal opinions allow it when the debtor is confidently able to pay debts back.

Debt is seen as source of humiliation during the day and anxiety during the night. The second Caliph 'Umar ibn al-Khattab (d. 644 CE) bases his cautioning on indebtedness on the very fact that debt begins with worry and ends with hostility. For instance, Qurtubi (d. 1273CE) elaborates on the effects of debt on the Muslim 
at the individual level in light of the following statement of Muslim scholars: "Debts are a disgrace and a humiliation as they preoccupy the mind and cause one to worry about paying it off. Debts also cause feelings of humiliation, particularly when meeting the lender, or a feeling that he is being done a favour when accepting a delay in payment. The debtor may potentially commit himself to paying off the debt then find himself unable but to break the promise; whereupon he may lie to the money lender, or even swear an oath to him then break it. The Debtor may also die without clearing his debt which will cause him to be confined for it". The following traditions of the Prophet reinforce this meaning: "When a man gets into debt, he speaks and tells lies and he makes a promise and breaks it". "The soul of the Muslim is held hostage by his debt in his grave until it is paid off." On the community level however, scholars have described the negative consequences and the dangers indebtedness poses to the economy; most notable among which is the desire for immediate gratification with no thought of the future, the lack of responsibility and self-reliance and the poor distribution of wealth.

Remarkably enough, when debts exhaust all the revenues of a Muslim person, they would then be described according to the teachings of Islam, as a poor (faqir) or needy (miskin) individual and thereby be entitled to financial support stemming from the community (Bensaid, 2013). After studying the indebtedness category of $z a k a h$ recipients from different views of Islamic scholars, this paper continued the discussion on the practice in Brunei Darussalam in the next section.

\section{Disbursement of Zakah to Al-Gharimun Category in Brunei Darussalam}

As mentioned earlier, to whom the zakah is eligible to be distributed is mentioned in al-Qur'an Surah Al-Taubah 9:60. There are eight categories of deserving persons mentioned in this verse. Among the eight categories are those who are in long-term poverty - the poor, the needy and the slaves. There are also those who are temporarily poor such as those in debt and wayfarers who need help. The other two categories ( $f$ sabilillah and muallaf) are for protection and propagation of Islam (jihad and dawah/preaching) and one category is for financing the $z a k a h$ institution's administrative costs (amil).

We categorize those indebted and wayfarer as temporarily poor because they will be able to survive on their own after they manage to pay all the debts and for the wayfarer after they get back to their home town with accessibility to their wealth.

\footnotetext{
${ }^{2}$ Narrated by al-Bukhari and Muslim
} 
Table 1: The Total Applications and Approval for Zakah under Al-Gharimun Category

\begin{tabular}{|c|c|c|c|c|c|}
\hline \multirow[t]{2}{*}{ Year } & \multicolumn{2}{|c|}{ Total Application Received } & \multirow{2}{*}{$\begin{array}{c}\text { Total } \\
\text { Applications } \\
\text { Approved }\end{array}$} & \multirow{2}{*}{$\begin{array}{c}\text { Total } \\
\text { Amount } \\
\text { approved } \\
\text { (estimation) } \\
\text { BND\$ }\end{array}$} & \multirow{2}{*}{$\begin{array}{c}\text { Total } \\
\text { Application } \\
\text { Rejected }\end{array}$} \\
\hline & $\begin{array}{l}\text { Category A (Loan on } \\
\text { Housing Scheme under } \\
\text { Housing Development } \\
\text { Department and } \\
\text { Yayasan Sultan Haji } \\
\text { Hassanal Bolkiah) }\end{array}$ & $\begin{array}{l}\text { Category } \\
\text { B (Debtors } \\
\text { other than } \\
\text { Housing } \\
\text { Scheme) }\end{array}$ & & & \\
\hline 2009 & 1767 & 1796 & $\begin{array}{l}\text { 412(Category } \\
\text { A) }\end{array}$ & $2,887,303$ & 0 \\
\hline 2010 & - & 514 & $\begin{array}{c}\text { 127(Category } \\
\text { A) }\end{array}$ & $1,513,394$ & 0 \\
\hline 2011 & - & 413 & 10 & 148,030 & 0 \\
\hline 2012 & - & 122 & 27 & 250,960 & 0 \\
\hline 2013 & - & 109 & 30 & 280,416 & 72 \\
\hline 2014 & - & 72 & 14 & 246,553 & 0 \\
\hline Total & 1767 & 3026 & 620 & $5,326,657$ & 72 \\
\hline
\end{tabular}

Source: Brunei Islamic Religious Council (MUIB)

Al-Gharimun can be defined in different way in different countries. For example, in Malaysia, Lembaga Zakah Selangor/Zakah Authority of Selangor stated that zakah for al-Gharim as 'to pay the liabilities of Muslims who are trapped in their obligations for their basic needs and provide humanity assistance for Muslims who have been the victims of disasters such as fires, floods, robberies, etc,' (Mustafa Murtala, 2008).

In the case of Brunei Darussalam, those in debt is defined by MUIB as 'the al-gharimun group is made up of those who have run into debt on building projects for the public such as the construction of mosques or schools. This definition is in line with the opinion of Shafi'is school of thought. Due to this definition, the proportion of zakah fund that allocated for al-gharimun category was accumulated since 1960s until 2009 to a big amount and has not being distributed because no eligible recipient available for it (Rose Abdullah, 2012).

However, an issue on the definition of al-gharimun was raised by His Majesty, Sultan of Brunei Darussalam in 2009 and urged to consider those who are in debt for basic necessities such as in debt for purchasing government houses to be considered under this category (The Brunei Times, 15 January 2009). 
Table 2: Types of Debt under category B

(Based on applications from 2009 - Sept 2013)

\begin{tabular}{|c|c|c|}
\hline No & Type of debt & Total Amount Applied \\
\hline 1 & Water & $\$ 2,632,866.98$ \\
\hline 2 & Electricity & $\$ 5,777,739.87$ \\
\hline 3 & Gas & 38089.36 \\
\hline 4 & Telephone & $\$ 724,318.78$ \\
\hline 5 & Government's Housing Scheme & $\$ 11,482,644.26$ \\
\hline 6 & Cukai Tanah & $\$ 141,059.92$ \\
\hline 7 & Housing Loan Scheme (Government Loan) & $\$ 1,230,023.39$ \\
\hline 8 & Government Car Loan & $\$ 220,822.34$ \\
\hline 9 & Muflis (Mahkamah) & $\$ 12,701,002.49$ \\
\hline 10 & Others (Debts to Government) & $\$ 2,235,139.24$ \\
\hline 11 & Personal Loan & $\$ 31,619,017.39$ \\
\hline 12 & Credit Card Loan & $\$ 5,763,035.21$ \\
\hline 13 & Bank's Housing Loan & $\$ 10,827,562.04$ \\
\hline 14 & Bank's Automobile Loan & $\$ 14,096,855.74$ \\
\hline 15 & Loan for Furnitures and Fittings & $\$ 1,468,887.13$ \\
\hline 16 & School fees & $\$ 58,402.32$ \\
\hline 17 & Loan to Personal Creditors & $\$ 1,115,219.59$ \\
\hline 18 & Guarantor & $\$ 930,715.64$ \\
\hline 19 & Pawnshop & $\$ 583,846.32$ \\
\hline 20 & Loan for Businesses & $\$ 5,074,933.98$ \\
\hline 21 & Debts for Legal Cases & $\$ 18,100.00$ \\
\hline 22 & Others (Non-Government) & $\$ 1,167,512.78$ \\
\hline \multicolumn{2}{|c|}{ Grand Total } & $\$ 109,907,794.77$ \\
\hline
\end{tabular}

Source: Brunei Islamic Religious Council (MUIB)

Therefore, some adjustments have been done and new guidelines have been used in disbursement of zakah fund for the category of al-gharimun. The recipients who are entitled to receive zakah under the category of Al-Gharimun will not receive 
the amount of cash to pay the debts but instead the MUIB's officer will pay off their debts directly to the creditors.

The application for zakah fund under the category of Al-Gharimun will have to go through three stages: First is the investigation on the applicants' debts. Then, the Verification Committee members will verify the application form. Finally, the Committee of Zakah Endorsement will endorse the zakah if the applicants are to be entitled as the recipients of Al-Gharimun. At this stage, the meeting will be held between the Al-Gharimun Department, the State Mufti and also the High Committees of Islamic Religious Council of Brunei to verify and approve the applications.

This study involved the data from 2009 until 2014 whereby, MUIB distributed the zakah fund under Al-Gharimun category in 3 phases; January 2009 until December 2009, January 2010 until December 2010 and January 2011 until October 2014.

The approved recipients of zakah fund under the category of Al-Gharimun in the first and second stages were mainly for debts on housing schemes both administered by Housing Development Department and Yayasan Sultan Haji Hassanal Bolkiah amounted to BND\$2,887,303 (412 persons) in 2009 and BND\$1,513,394 (127 persons) in 2010 as shown in Table 1. For the third stage, only 81 applicants were approved amounted to BND\$925,969 which were for various types of debts. 72 applicants were rejected in 2013 while the rest more than 4000 applications are still pending for consideration process (Hartina, 2 June 2015; Muhd Fahmi, 2 June 2015).

Table 3: Number of Applicants according to Income Groups (2009 - 2013)

\begin{tabular}{|c|c|c|c|c|c|c|c|c|c|}
\hline \multicolumn{10}{|c|}{ Income } \\
\hline No & Phase & $\begin{array}{l}\mathscr{\Xi} \\
\ddot{\Xi} \\
\Xi \\
\dot{0}\end{array}$ & 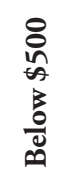 & $\begin{array}{l}8 \\
8 \\
0 \\
1 \\
1 \\
0 \\
0 \\
n \\
n\end{array}$ & 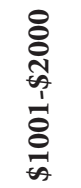 & 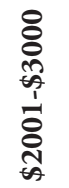 & $\begin{array}{l}8 \\
8 \\
+ \\
+1 \\
1 \\
8 \\
0 \\
0 \\
0\end{array}$ & 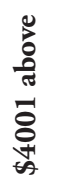 & Total \\
\hline 1 & First & 149 & 149 & 232 & 274 & 50 & 4 & 4 & 862 \\
\hline 2 & Second & 110 & 122 & 198 & 356 & 66 & 16 & 7 & 875 \\
\hline \multirow[t]{2}{*}{3} & Third & 279 & 293 & 229 & 231 & 40 & 6 & 6 & 1094 \\
\hline & Grand Total & 538 & 564 & 669 & 861 & 156 & 26 & 17 & 2831 \\
\hline
\end{tabular}

Source: Brunei Islamic Religious Council (MUIB) 
The applications under the category B, which consist of various types of debts are shown in Table 2. Debts in bills like water, electricity, gas and phone. There are also debts in housing scheme, land tax, housing loan scheme, transport scheme, bankruptcy (court), others (Government), personal loan, credit card loans, home loan, car loans, furniture loans, overdue school fees, private, guarantor, mortgage, business loans, legal debt and other (Non-Government) loans. The figure shows the types of debts and the amount (in total) being applied. Personal Loan was the highest at $29 \%$ valued at about $\$ 31.6$ million. The second highest debts being applied for under the category of $\mathrm{Al}$-Gharimun is Car loan at BND $\$ 14.1$ million. While, those who already declared bankruptcy amounted to BND $\$ 12.7$ million.

It seems that the number of applicants for various types of debt in category $\mathrm{B}$ were double of category A. MUIB found that the applicants do not understand the meaning of al-gharimun. A new guide line is needed for this category since previously the al-gharimun is for those in debt due to public expenditure such as building mosque, madrasah, school etc. As can be seen from Table 3 the number of applicants increases by $1.5 \%$ from 862 applicants (2009) to 875 applicants (2010). The data has shown that about $20 \%$ of the applicants are unemployed and about $40 \%$ earned below BND $\$ 1,000$.

\section{Conclusion}

Though zakah and charity (sadaqah) are normal practices in Muslim societies, their emotional implications are far less apparent. Receiving charity is not always pleasant, particularly for those whose financial needs force them to shift their respective social status from the donor to a receiver. Furthermore, the debtor's religious life cannot be distanced from the life of the community, which seeks to continually sustain favourable avenues for regarding spiritual and intellectual education, socialization and support. For debtors however, such highly communal religious occasions may turn into causes of embarrassment, increased stress and frustration. Should a Muslim debts force the Muslim to avoid community life, he may then skip a number of communal obligations and would have also consequently violated a number of religious instructions concerning adherence to the Jama'ah (group and community).

In the case of Brunei Darussalam, zakah management has experienced some changes conceptually and by practice after the issues of zakab in 2009. This is especially in relation to al-gharimun category. The debts that considered for $z a k a h$ eligibility are not only due to public requirements and needs but also considered for personal basic needs. 


\section{References}

Al Abdin, Al-Tayib Zein, (2002). The Distribution of Zakah, International Training Seminar on Zakah Management, May 20-23, 2002, International Islamic University, Islamabad, Pakistan and Islamic Research and Training Institute (IDB), Pakistan.

Al-Bukhari, Muhammad ibn Ismail. (1407/1987). Al-Jami' al-Sahih. Beirut: Dar al-Qalam.

Al-Mawardi, Ali bin Muhammad. (1386/1966). Al-Ahkam al-Sultaniyyah wa alWilayat al-Diniyyah. Cairo: Mustafa al-Babi al-Halabi.

Al-Shirbini, M. al-Khatib. (n.d). Mughni al-Muhtaj ila Márifah Alfaz al-Manhaj. Dar al-Fikr

Al-Qardawi, Y. (2005). Figh al-Zakah. Trans. Monzer Kahf. Jeddah, Saudi Arabia: Scientific Publishing Center.

Al-Zuhaili, W. (1989). Al-Fiqh al-Islami wa Adillatuhu vol.4, Damascus: Dar al-Fikr al-Islami,

Benaouda Bensaid, Fadila Grine, Mohd Roslan Mohd Nor and Mohd Yakub Zulkifli Mohd Yusoff. (2013), "Enduring Financial Debt: An Islamic Perspective" Middle-East Journal of Scientific Research, 13 (2): 162-170.

Daud, A.S. (1952). Sunan Abi Daud. Cairo: Mustafa al-Babi al-Halabi.

Duriau, V. et.al. (2007). A Content Analysis of the Content Analysis Literature in Organization Studies: Research Themes, Data Sources, and Methodological Refinements. Organization Research Methods, 10: 5-34.

Ibn Nujaim, Z. (1997). al-Bahr al-Ra’iq. Beirut: Dar al-Kutub al-'Ilmiyyah.

Muslim, H. (1956). Sahih Muslim. Beirut: Dar al-Turath al-'Arabi.

Mustafa Murtala Oladimeji Abioye. (2008), "Accountability for Zakah Disbursement an Exploratory Study of Empowerment Schemes in Zakah Institutions", a master degree dissertation, Malaysia: IIUM.

Mohyuddin Mahboob, P.S.M. (2010). Handling Debt in Islam. http://nabikeghulam. blogspot.com/2010/07/handling-debt-in-islam.html. Accessed in December $15,2016$.

Pfarrer, M.D. et.al. (2010). A Tale of Two Assets: The Effects of Firm Reputation and Celebrity on Earnings Surprises and Investors' Reactions. Academy of Management Journal, 53: 1131-1152. 